\title{
PENINGKATAN MOTORIK HALUS ANAK MELALUI KEGIATAN MEROBEK KERTAS PADA ANAK USIA 4-5 TAHUN TK NEGERI 2 SAMARINDA
}

\author{
Vivi Endang Adiningsih \\ PG PAUD Universitas Widya Gama Mahakam Samarinda \\ viviafandi26@gmail.com \\ Rizqi Syafrina \\ PG PAUD Universitas Widya Gama Mahakam Samarinda \\ nonon11185@gmail.com
}

\begin{abstract}
Children cannot use their fine motoric skill well in paper-tearing activity. It seems that there are still many children who do not participate in the paper tearing activity, as exemplified by the teacher. This is proven when children do paper tearing activities. The aim of this research is to improve children's fine motor skills through paper tearing on children aged 4-5 years. The method used in this study is classroom action research (CAR) and a descriptive research which carried out in two cycles consisting of 3 meetings in each cycle. Research procedures that were carried out in this study were planning, implementation, observation and reflection. The subjects of this study were 19 children aged 4-5 years, consisted of 7 boys and 12 girls. The results showed that the children's fine motor skills improved compared to the pre-cycle phase. In cycle I, there was an increase from pre-cycle with an average value of $31.3 \%$ to $60.9 \%$ through the first, second and third meeting and succeeded in the second cycle through the first, second and third meeting with an average value of $87.4 \%$ in which this value has reached the target of success indicator that is $85 \%$. Based on the results of the study, it can be concluded that paper tearing activity can improve children aged 4-5 years' fine motoric skills and it is suggested to kindergarten teachers to make paper tearing activities as a media for improving children's fine motoric skills.
\end{abstract}

Keywords: kindergarten student, fine motoric skill, paper tearing 


\section{PENDAHULUAN}

Anak usia dini (0-8 tahun) adalah individu yang sedang mengalami proses pertumbuhan dan perkembangan yang sangat pesat. Bahkan dikatakan sebagai the golden age (usia emas), yaitu usia yang sangat berharga dibandingkan usia-usia selanjutnya (Susanto, 2017).

Pendidikan anak usia dini merupakan salah satu bentuk penyelenggaraan pendidikan yang menitikberatkan pada peletakan dasar ke arah pertumbuhan dan perkembangan fisik (koordinasi motorik halus dan kasar), kecerdasan (daya pikir, daya cipta, kecerdasan emosi, kecerdasan spiritual), sosioemosional (sikap dan perilaku serta agama), bahasa dan komunikasi, yang disesuaikan dengan keunikan dan tahaptahap perkembangan yang dilalui oleh anak usia dini (Suryadi, 2014).

Kegiatan bermain anak akan bereksplorasi, menemukan dan memanfaatkan objek-objek yang dekat dan menarik bagi anak sehingga pembelajaran lebih bermakna dan menimbulkan rasa kesenangan serta kepuasan bagi anak sehingga dapat mengembangkan sebagian besar potensi dalam dirinya. MS Sumantri (Mulyati, 2014) menjelaskan bahwa Pendidik anak usia dini perlu menekankan pentingnya kegiatan bermain atau pengembangan motorik lainnya. Ada dua hal yang seyogyanya tidak dilupakan oleh pendidik adalah pertama pemahaman akan pentingnya hubungan kegiatan dengan pengembangan daya pikir dan daya cipta anak, kedua bila anak tanpa bebas bergerak, tanpa menjelajahi lingkungan, tanpa bermain anak akan kurang tumbuh dan berkembang secara optimal.

Perkembangan aspek motorik halus erat kaitannya dengan masalah perkembangan fisik. Ketika otot-otot badan cenderung lebih kuat dan kokoh, maka keterampilan-keterampilan yang menggunakan otot tangan dan kaki sudah mulai berfungsi. Perkembangan fisik seperti berjalan, berlari, melompat, menggunting, menempel dan sebagainya membutuhkan keterampilan motorik halus agar otot dan syaraf yang mulai tumbuh dapat berfungsi dengan baik. Secara umum, perkembangan fisik motorik anak usia dini mencakup motorik kasar (gross motor skills) dan motorik halus (fine motor skills) (Mulyani, 2018). Menurut Zulkifli (Mulyani, 2018) menjelaskan bahwa perkembangan motorik halus adalah gerakan-gerakan tubuh yang dimotori dengan kerjasama antar otot, otak dan saraf. Ciri-ciri gerakan motorik halus ialah dilakukan dengan tidak sengaja, tidak ditujukan untuk maksud-maksud tertentu.

Semakin baiknya gerakan motorik halus anak membuat anak dapat berkreasi, seperti menggunting kertas dengan hasil guntingan yang lurus, menggambar gambar sederhana dan mewarnai, menggunakan klip untuk menyatukan dua lembar kertas, menjahit, menganyam kertas serta 
menajamkan pensil dengan rautan pensil.

Namun, tidak semua anak memiliki kematangan untuk menguasai kemampuan ini pada tahap yang sama (Sujiono, 2014).

Salah satu kegiatan untuk mengembangkan motorik halus anak-anak adalah dengan melalui kegiatan merobek kertas. Berdasarkan pengamatan peneliti pada anak usia 4-5 tahun di TK Negeri 2 Samarinda pengembangan motorik halus anak melalui kegiatan menggambar, mewarnai, menganyam, melipat, merobek dan lain-lain masih belum maksimal. Terlihat masih banyak anak yang kurang mengikuti kegiatan merobek kertas yang dicontohkan oleh guru. Dari 19 anak terdapat 4 anak yang sudah bisa melakukan kegiatan merobek kertas tanpa dibantu, 5 anak sudah bisa melakukan kegiatan walaupun pada awal kegiatan masih dibantu guru, terdapat 6 anak yang masih minta bantuan guru dari awal sampai akhir dan bahkan terdapat 4 anak yang sama sekali tidak mengerti bagaimana merobek kertas dengan baik. Hal ini terjadi karena masih rendahnya kemampuan anak untuk mengontrol gerakan jari jemarinya sehingga pada saat melakukan kegiatan terkesan gerakan anak masih ragu-ragu dan canggung.

Berdasarkan hasil pengamatan pada anak usia 4-5 tahun di TK Negeri 2 Samarinda sebanyak 15 dari 19 anak masih kesulitan melibatkan kegiatan motorik halus seperti kegiatan merobek kertas. Hal tersebut terlihat pada saat kegiatan merobek kertas dimana anak-anak diminta untuk merobek sendiri kertas yang digunakan untuk kegiatan kolase, terlihat ada beberapa anak yang sudah bisa mengikuti arahan walaupun masih ada yang meminta bantuan guru namun ada beberapa anak yang diam dan kebingungan memegang kertas sehingga kertasnya tidak dirobek sama sekali. Aktivitas anak dalam keterampilan menggerakkan motorik halus pada kegiatan merobek kertas masih belum terampil. Penyebab lainnya terlihat ada beberapa anak yang bermain sendiri atau dengan temannya ketika guru sedang menjelaskan sehingga pada saat melakukan kegiatan mereka masih kesulitan.

Pentingnya kegiatan merobek kertas karena kegiatan ini menyenangkan dan menghasilkan sensasi tersendiri yang dapat ditangkap oleh indera anak, kegiatan merobek kertas juga melibatkan unsur otot, syaraf, otak, dan jari-jemari tangan. Anak selayaknya diberi motivasi, dorongan yang dapat memunculkan minat anak terhadap kegiatan tersebut. Anak dilatih merobek bebas dengan benar kemudian bertahap pola sederhana dilanjutkan pola benda tertentu, sehingga dapat meningkatkan kelenturan jari jemari anak. Unsur-unsur tersebut akan terkoordinasi jika dilakukan dengan intensif. Tak ada seorang anak pun yang tidak gemar merobek. Saat diberi secarik kertas, ia akan dengan sigap memegangnya apalagi diminta merobek kertas tersebut. Karena itu, merobek dianggap dapat dijadikan sebagai ajang mengasah kreativitas anak. Selain itu, 
aktivitas ini juga bermanfaat dapat menstimulasi daya imajinasi, mengembangkan gagasan, menyalurkan emosi, menumbuhkan minat seni, sekaligus mengoptimalkan kemampuan motorik halus anak prasekolah (Pratiwi, 2016).

\section{METODE PENELITIAN}

\section{Jenis Penelitian}

Jenis penelitian yang digunakan adalah penelitian tindakan kelas, merupakan salah satu bentuk peneliatan yang dilakukan di kelas (Paizaluddin, 2016).

Menurut Kardiawarman (Muliawan, 2018) Penelitian tindakan kelas (Classroom Action Research) adalah penelitian yang dilakukan pada sebuah kelas untuk mengetahui akibat tindakan yang diterapkan pada suatu subyek penelitian di kelas tersebut.

\section{Tempat dan Waktu Penelitian}

Peneliti melakukan penelitian ini di salah satu Taman Kanak-kanak yang beralamatkan di jalan Jakarta Blok EO No.1 Kelurahan Loa Bakung, Kecamatan Sungai Kunjang, Samarinda. Dalam penelitian ini peneliti mengambil 2 siklus yang terdiri dari 1 siklus 3 kali pertemuan.

\section{Subjek dan Objek Penelitian}

Subjek penelitian ini adalah anak berusia 4-5 tahun Sentra Seni TK Negeri 2 Samarinda yang berjumlah 19 orang, terdiri dari 7 orang laki-laki dan 12 orang perempuan.

\section{Prosedur Penelitian}

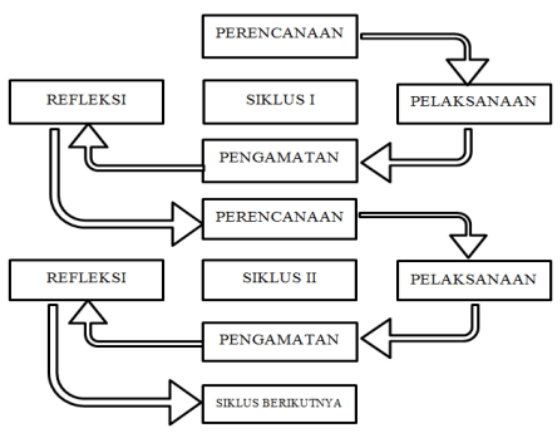

Gambar.1 Alur Penelitian Tindakan Kelas model Arikunto (Arikunto, 2008)

Langkah-langkah dalam penelitian ini sama disetiap siklusnya. Prosedur pelaksanaan tindakan kelas terdiri dari empat langkah yaitu perencanaan (plan), pelaksanaan (act), pengamatan (observe) dan refleksi (reflect) berikut penjelasannya. pelaksanaan tindakan pada setiap siklus (Sugiyono, 2015).

\section{Metode Pengumpulan Data}

\section{Observasi}

Observasi yang dilakukan dalam penelitian ini yaitu pengumpulan data dengan cara peneliti terlibat langsung dalam kegiatan belajar mengajar (Participant Observation) dengan anak dan penilaian terhadap anak meliputi: ketelitian, keluwesan dan kerapian anak dalam kegiatan merobek kertas.

\section{Dokumentasi}

Menurut Arikunto (Mulyati, 2014) Dokumentasi berasal dari kata dokumen yang artinya barang-barang tertulis. Metode dokumentasi merupakan cara pengumpulan data yang berupa gambar (foto) dan catatan. 


\section{Instrumen Penelitian}

Instrumen pengumpulan data yang digunakan dalam penelitian ini adalah dokumentasi berupa foto dan lembar observasi menggunakan check list.

1. Nilai rata-rata ini didapat dengan menggunakan rumus:

$$
X=\frac{\sum x i}{n}
$$

(Fahmi, 2018)

Keterangan:

$\mathrm{X}=$ Nilai rata-rata anak yang tuntas belajar

$\mathrm{n}=$ Jumlah keseluruhan aspek penilaian

$\sum x i=$ Jumlah nilai anak yang tuntas belajar

2. Persentase digunakan untuk menentukan ketuntasan skor dasar dari siklus I dan siklus II dengan menggunakan rumus:

$$
\mathrm{P}(\% \text { tuntas })=\frac{\sum f i}{n} \times 100 \%
$$

Keterangan :

$\sum f i \quad=$ Jumlah anak pada kategori ketuntasan belajar

$\mathrm{n}$ = Jumlah anak secara keseluruhan

\section{Indikator Keberhasilan}

Indikator yang menjadi tolak ukur dalam penelitian ini yang menyatakan bahwa kegiatan merobek kertas dapat meningkatkan keterampilan motorik halus anak apabila keterampilan anak mengalami peningkatan dari setiap siklus atau berada pada kriteria Berkembang Sesuai Harapan (BSH) dan
Berkembang Sangat Baik (BSB) dengan persentase $85 \%$.

\section{Hasil Penelitian Dan Pembahasan}

\section{Hasil Penelitian}

\section{Kondisi Awal Pra Siklus}

Kemampuan awal sebelum tindakan pada akhirnya akan dibandingkan dengan hasil setelah dilaksanakan tindakan melalui kegiatan merobek kertas. Perbandingan bertujuan untuk menunjukkan adanya peningkatan sebelum dan sesudah dilaksanakan tindakan. Hasil observasi keterampilan motorik halus pratindakan anak usia 4-5 tahun TK Negeri 2 Samarinda dengan menggunakan instrumen lembar observasi checklist hasilnya dalam tabel dan grafik di bawah ini:

Tabel .1 Data Keterampilan Motorik Halus Pra Siklus Anak

\begin{tabular}{|c|c|c|c|c|c|c|c|c|c|}
\hline \multirow[t]{3}{*}{ No } & \multicolumn{6}{|c|}{ Aspek Penilaian Motorik Halus } & \multirow{3}{*}{$\begin{array}{l}\mathbf{S} \\
\mathbf{k} \\
\mathbf{o} \\
\mathbf{r}\end{array}$} & \multirow{3}{*}{$\begin{array}{l}\text { Ka } \\
\text { teg } \\
\text { ori }\end{array}$} & \multirow{3}{*}{$\begin{array}{l}\text { Juml } \\
\text { ah } \\
\text { rata- } \\
\text { rata }\end{array}$} \\
\hline & \multicolumn{2}{|c|}{$\begin{array}{c}\text { Ketelitia } \\
\text { n }\end{array}$} & \multicolumn{2}{|c|}{$\begin{array}{c}\text { Keluwes } \\
\text { an }\end{array}$} & \multicolumn{2}{|c|}{$\begin{array}{c}\text { Kerapia } \\
\text { n }\end{array}$} & & & \\
\hline & $\begin{array}{c}\mathrm{Jm} \\
\mathrm{lh}\end{array}$ & $\%$ & $\begin{array}{c}\mathrm{Jm} \\
\mathrm{lh}\end{array}$ & $\%$ & $\begin{array}{c}\mathrm{Jm} \\
\mathrm{lh}\end{array}$ & $\%$ & & & \\
\hline 1 & 6 & $\begin{array}{c}33, \\
3 \\
\%\end{array}$ & 1 & $\begin{array}{c}5,5 \\
\%\end{array}$ & 4 & $\begin{array}{c}22, \\
2 \\
\%\end{array}$ & 1 & $\begin{array}{l}\text { B } \\
\text { B }\end{array}$ & $\begin{array}{c}20,3 \\
\%\end{array}$ \\
\hline 2 & 8 & $\begin{array}{c}44 \\
4 \\
\%\end{array}$ & 9 & $\begin{array}{l}50 \\
\%\end{array}$ & 9 & $\begin{array}{l}50 \\
\%\end{array}$ & 2 & $\begin{array}{l}\mathrm{M} \\
\mathrm{B}\end{array}$ & $\begin{array}{c}48,1 \\
\%\end{array}$ \\
\hline 3 & 3 & $\begin{array}{c}16, \\
6 \\
\%\end{array}$ & 7 & $\begin{array}{c}38, \\
8 \\
\%\end{array}$ & 3 & $\begin{array}{c}16, \\
6 \\
\%\end{array}$ & 3 & $\begin{array}{c}\mathrm{BS} \\
\mathrm{H}\end{array}$ & $24 \%$ \\
\hline 4 & 1 & $\begin{array}{c}5,5 \\
\%\end{array}$ & 1 & $\begin{array}{c}5,5 \\
\%\end{array}$ & 2 & $\begin{array}{c}11, \\
1 \\
\%\end{array}$ & 4 & $\begin{array}{c}\text { BS } \\
\text { B }\end{array}$ & $7,3 \%$ \\
\hline & & $\mathrm{N}$ & & & & & & & $\begin{array}{c}31,3 \\
\% \\
\end{array}$ \\
\hline
\end{tabular}
Usia 4-5 Tahun

Sumber data lembar observasi anak pra siklus (lampiran)

Berdasarkan di atas tersebut dapat diketahui bahwa keterampilan motorik halus anak belum berkembang dengan baik. Hal ini dapat dilihat dari hasil data keterampilan motorik halus pra siklus anak usia 4-5 tahun yang memperoleh rata-rata $31,3 \%$. Hal ini 
belum mencapai target indikator keberhasilan yaitu dengan persentase $85 \%$. Oleh karena itu, diperlukan tindakan untuk meningkatkan keterampilan motorik halus melalui kegiatan merobek kertas pada anak usia 4-5 tahun di TK Negeri 2 Samarinda.

\section{Deskripsi Hasil Penelitian}

\section{a. Pelaksanaan Tindakan Siklus I}

Perencanaan

Siklus I yang dilaksanankan pada tanggal 09, 16 Agustus dan 16 September 2019. Perencanaan tindakan pertemuan pertama dibuat sesuai dengan tema diriku. Langkah-langkah yang dilakukan peneliti dalam tahap perencanaan ini adalah:

1. Peneliti menentukan tema, sub tema dan topik yang akan dibahas sesuai dengan program sekolah.

2. Membuat Rencana Pelaksanaan Pembelajaran Harian (RPPH) dan Rencana Pelaksanaan Pembelajaran Mingguan (RPPM), sebagai acuan peneliti dalam melaksanakan penelitian.

3. Mempersiapkan instrumen penelitian, instrumen yang digunakan berupa lembar observasi untuk guru dan anak.

4. Menyiapkan media pembelajaran berupa alat dan bahan yang akan digunakan dalam proses pembalajaran.

Pelaksanaan

$$
\text { Kegiatan awal }( \pm 30 \quad \text { menit })
$$

pembelajaran dimulai dengan baris, berdoa, dan senam sehat dihalaman sekolah. Selanjutnya anak-anak diarahkan masuk kelas kemudian duduk dengan rapi. berdoa bersama, bernyanyi bersama, peneliti mengabsen anak dan menanyakan kabarnya. Sebelum masuk pada materi pembelajaran peneliti bercakap-cakap sesuai dengan tema dan menjelaskan aturan main. Selanjutnya guru menjelaskan kegiatan inti yang akan dilakukan pada hari itu.

Kegiatan Inti $( \pm 60$ menit $)$ disini peneliti menjelaskan kegiatan-kegiatan yang akan dilakukan pada hari itu. Kegiatan merobek kertas bergambar boneka dengan arah vertikal yang sebelumnya dilipat menjadi 3 lipatan sejajar kemudian hasil sobekan tersebut ditempel pada kertas HVS putih sesuai pola atau gambar boneka. Peneliti menjelaskan kegiatan merobek kertas yang akan dilakukan yaitu membuat sobekan dengan arah vertikal menggunakan kertas HVS warna kuning yang bergambar boneka, kemudian guru mendemonstrasikan tahapan bagaimana merobek dengan rapi.

Kegiatan pembelajaran berlangsung dan peneliti mengamati anak yang sedang melakukan kegiatan merobek kertas. Setelah selesai kegiatan merobek anak-anak mengumpulkan hasil kegiatan mereka kemudian membereskan alat main. Pada kegiatan akhir peneliti melakukan evaluasi kegiatan sehari, menanyakan bagaimana perasaan mereka, berdoa menutup pembelajaran dan mengucap salam $( \pm 15$ menit).

Observasi

Observasi pada siklus 1 pertemuan 1 yang dilakukan meliputi pengamatan 
kegiatan merobek kertas meliputi ketelitian terdapat 3 anak (20\%) dengan kategori berkembang sesuai harapan (BSH) dan 2 $(13,3 \%)$ anak dengan kategori berkembang sangat baik (BSB). Keluwesan terdapat 6 anak (40\%) dengan kategori berkembang sesuai harapan (BSH) dan 4 anak $(26,6 \%)$ dengan kategori berkembang sangat baik (BSB). Kerapian terdapat 3 anak (20\%) dengan kategori berkembang sesuai harapan (BSH) dan 4 anak (26,6\%) dengan kategori berkembang sangat baik (BSB). Hasil data analisis observasi Siklus I pada pertemuan pertama yaitu ketelitian 33,3\%, keluwesan $66,6 \%$ dan kerapian $46,6 \%$. Nilai rata-rata ketuntasan kemampuan motorik halus siklus I pada pertemuan pertama $48,8 \%$.

Observasi siklus 1 pertemuan 2 yang dilakukan meliputi pengamatan terhadap aktivitas anak selama pembelajaran berlangsung melalui kegiatan merobek kertas meliputi ketelitian terdapat 5 anak $(35,7 \%)$ dengan kategori berkembang sesuai harapan (BSH) dan 4 anak (28,5\%) dengan kategori berkembang sangat baik (BSB). Keluwesan terdapat 7 anak (50\%) dengan kategori berkembang sesuai harapan (BSH) dan 3 anak $(21,4 \%)$ dengan kategori berkembang sangat baik (BSB). Kerapian terdapat 3 anak $(21,4 \%)$ dengan kategori berkembang sesuai harapan (BSH) dan 3 anak (21,4 \%) dengan kategori berkembang sangat baik (BSB). Berdasarkan hasil data analisis observasi Siklus I pada pertemuan kedua yaitu ketelitian $64,2 \%$, keluwesan $71,4 \%$ dan kerapian $42,8 \%$. Nilai rata-rata ketuntasan kemampuan motorik halus siklus I pada pertemuan kedua 59,4\%.

Observasi siklus 3 pertemuan 3 dilakukan bersama dengan pelaksanaan kegiatan belajar mengajar. Observasi yang dilakukan meliputi pengamatan terhadap aktivitas anak selama pembelajaran berlangsung melalui kegiatan merobek kertas meliputi ketelitian terdapat 6 anak $(46,1 \%)$ dengan kategori berkembang sesuai harapan (BSH) dan 4 anak $(30,7 \%)$ dengan kategori berkembang sangat baik (BSB). Keluwesan terdapat 6 anak $(46,1 \%)$ dengan kategori berkembang sesuai harapan (BSH) dan 5 anak $(38,4 \%)$ dengan kategori berkembang sangat baik (BSB). Kerapian terdapat 5 anak $(38,4 \%)$ dengan kategori berkembang sesuai harapan (BSH) dan 3 anak (23,7\%) dengan kategori berkembang sangat baik (BSB). Berdasarkan hasil data analisis observasi Siklus I pada pertemuan ketiga yaitu ketelitian 76,8\%, keluwesan $84,5 \%$ dan kerapian $62,1 \%$. Nilai rata-rata ketuntasan kemampuan motorik halus siklus I pada pertemuan ketiga sudah mulai meningkat yaitu $74,4 \%$.

Refleksi

Refleksi pada siklus 1 Selama kegiatan berlangsung ada beberapa masalah yang dihadapi yaitu sebagai berikut:

1) Waktu yang kurang efisien karena hari Jumat anak-anak cepat pulang. Pada saat peneliti mengajar terlalu terburu-buru dan setelah selesai mengajar anak-anak 
melanjutkan belajar bahasa inggris sehingga pada hari itu peneliti tidak sempat menutup pembelajaran.

2) Tempat yang kurang kondusif karena pada hari penelitian peneliti ditempatkan di aula sekolah yang luas. Pada saat mengajar terdapat beberapa anak berlarilarian dan beberapa orang tua juga ikut duduk dalam aula sekolah dan anak lebih memilih duduk dekat dengan orang tuanya.

3) Antusias anak masih kurang, karena terdapat beberapa anak yang berlarian, memilih duduk dengan orang tuanya, bermain dengan temannya sehingga tidak memperhatikan guru ketika menjelaskan pembelajaran.

4) Peneliti merasa gugup karena mengajar tepat dihadapan orang tua anak.

5) Rata-rata pada aspek ketelitian dan kerapian pada saat kegiatan merobek dan menempel masih banyak anak yang masih rendah. Salah satunya disebabkan anak merasa tangannya kotor dan tidak nyaman ketika menggunakan lem.

6) Waktu yang kurang efisien karena hari Jumat anak-anak cepat pulang. Pada saat peneliti mengajar terlalu terburu-buru dan setelah selesai mengajar anak-anak melanjutkan belajar bahasa inggris.

7) Tempat penelitian di pertemuan ini berada di ruangan kelas, tetapi masih terdapat beberapa orang tua ikut masuk dalam kelas sehingga membuat beberapa anak tidak konsentrasi saat guru menjelaskan pembelajaran.

8) Rata-rata pada aspek ketelitian dan kerapian pada pertemuan kedua ini sudah mulai meningkat walaupun pada saat kegiatan menempel masih ada beberapa anak merasa tangannya kotor dan tidak nyaman ketika menggunakan lem.

Tabel .2 Rekapitulasi Keterampilan Motorik Halus Anak Melalui Kegiatan Merobek Kertas Siklus I

\begin{tabular}{|c|l|l|l|l|l|}
\hline No & $\begin{array}{l}\text { Aspek yang } \\
\text { dinilai }\end{array}$ & P1 & P2 & P3 & $\begin{array}{c}\text { Nilai } \\
\text { rata-rata }\end{array}$ \\
\hline 1 & Ketelitian & $\begin{array}{l}33,3 \\
\%\end{array}$ & $\begin{array}{l}64,2 \\
\%\end{array}$ & $\begin{array}{l}76,8 \\
\%\end{array}$ & $58,1 \%$ \\
\hline 2 & Keluwesan & $\begin{array}{l}66,6 \\
\%\end{array}$ & $\begin{array}{l}71,4 \\
\%\end{array}$ & $\begin{array}{l}84,5 \\
\%\end{array}$ & $74,1 \%$ \\
\hline 3 & Kerapian & $\begin{array}{l}46,6 \\
\%\end{array}$ & $\begin{array}{l}42,8 \\
\%\end{array}$ & $\begin{array}{l}62,1 \\
\%\end{array}$ & $50,5 \%$ \\
\hline \multicolumn{6}{|c|}{ Nilai ketuntasan siklus I } \\
\hline
\end{tabular}

\section{b. Pelaksanaan Tindakan Siklus II}

Perencanaan

Siklus II pertemuan yang dilaksanakan 15,20 dan 23 September 2019. Perencanaan tindakan pertemuan pertama dibuat sesuai dengan tema alam semesta, sub tema gejala alam dan topik yang dibahas pelangi. Langkah-langkah yang dilakukan peneliti dalam tahap perencanaan ini adalah:

1. Peneliti menentukan tema, sub tema dan topik yang akan dibahas sesuai dengan program sekolah.

2. Membuat Rencana Pelaksanaan Pembelajaran Harian (RPPH) dan Rencana Pelaksanaan Pembelajaran Mingguan (RPPM), sebagai acuan peneliti dalam melaksanakan penelitian. 
3. Mempersiapkan instrumen penelitian, instrumen yang digunakan berupa lembar observasi untuk guru dan anak.

4. Menyiapkan media pembelajaran berupa alat dan bahan yang akan digunakan dalam proses pembalajaran yaitu pola pelangi yang akan dirobek, kertas untuk menempel pola tersebut, lem kertas, kertas warna warni untuk kolase pelangi, pola pemandangan untuk diwarnai dan pensil warna.

Pelaksanaan

Pertemuan pertama pada siklus Kegiatan awal (90 menit) pembelajaran dimulai dengan baris berbaris sambil bernyanyi di depan kelas kemudian anak masuk kelas, salam dan duduk di karpet, berdoa bersama, bernyanyi bersama, mengabsen anak dan menanyakan kabar. Pada kegiatan selanjutnya anak dipersilahkan bermain bebas di dalam kelas sambil mengaji.

Kegiatan selanjutnya anak bersiapsiap pergi sholat bersama dimusollah sekolah \pm 30 menit. Selanjutnya anak senam ringan dan bermain bebas diluar ruangan \pm 30 menit. Pada kegiatan selanjutnya anak bersiap-siap mencuci tangan sambil bernyanyi lagu 6 langkah mencuci tangan kemudian berbaris mengantri \pm 30 menit.

Kegiatan Inti (75 menit), sebelum masuk pada materi pembelajaran dan bercakap-cakap sesuai dengan tema. Kemudian guru menjelaskan aturan main. Peneliti menjelaskan kegiatan-kegiatan yang akan dilakukan pada hari itu. Kegiatan merobek kertas bergambar pelangi mengikuti pola gambarnya, kemudian hasil sobekan tersebut ditempel pada kertas HVS putih. kemudian peneliti mendemonstrasikan tahapan bagaimana merobek kertas. Kegiatan akhir peneliti melakukan evaluasi dan penutup (30 menit).

Observasi

Observasi siklus 2 pertemuan 1 yang dilakukan meliputi pengamatan terhadap aktivitas anak selama pembelajaran berlangsung melalui kegiatan merobek kertas meliputi ketelitian terdapat 7 anak $(46,6 \%)$ dengan kategori berkembang sesuai harapan (BSH) dan 6 anak (40\%) dengan kategori berkembang sangat baik (BSB). Keluwesan terdapat 7 anak $(46,6 \%)$ dengan kategori berkembang sesuai harapan (BSH) dan 7 anak (46,6 \%) dengan kategori berkembang sangat baik (BSB). Kerapian terdapat 5 anak (33,3\%) dengan kategori berkembang sesuai harapan (BSH) dan 4 anak $(26,6 \%)$ dengan kategori berkembang sangat baik (BSB). Berdasarkan hasil data analisis observasi Siklus II pada pertemuan pertama yaitu ketelitian 86,6\%, keluwesan 93,2\% dan kerapian $59,9 \%$. Nilai rata-rata ketuntasan kemampuan motorik halus Siklus II pada pertemuan pertama yaitu $79,9 \%$.

Observasi siklus 2 pertemuan 2 yang dilakukan meliputi pengamatan terhadap aktivitas anak selama pembelajaran 
berlangsung melalui kegiatan merobek kertas meliputi ketelitian terdapat 6 anak (40\%) dengan kategori berkembang sesuai harapan (BSH) dan 8 anak $(53,3 \%)$ dengan kategori berkembang sangat baik (BSB). Keluwesan terdapat 6 anak (40\%) dengan kategori berkembang sesuai harapan (BSH) dan 9 anak (60\%) dengan kategori berkembang sangat baik (BSB). Kerapian terdapat 7 anak $(46,6 \%)$ dengan kategori berkembang sesuai harapan (BSH) dan 4 anak $(26,6 \%)$ dengan kategori berkembang sangat baik (BSB). Berdasarkan hasil data analisis observasi Siklus II pada pertemuan kedua yaitu ketelitian 93,3\%, keluwesan $100 \%$ dan kerapian $73,2 \%$. Nilai rata-rata ketuntasan kemampuan motorik halus Siklus II pada pertemuan kedua yaitu $88,8 \%$.

Observasi siklus 2 pertemuan 3 yang dilakukan meliputi pengamatan terhadap aktivitas anak selama pembelajaran berlangsung melalui kegiatan merobek kertas meliputi ketelitian terdapat 7 anak $(43,7 \%)$ dengan kategori berkembang sesuai harapan (BSH) dan 9 anak $(56,2 \%)$ dengan kategori berkembang sangat baik (BSB). Keluwesan terdapat 4 anak (25\%) dengan kategori berkembang sesuai harapan (BSH) dan 12 anak (75\%) dengan kategori berkembang sangat baik (BSB). Kerapian terdapat 6 anak (37,5\%) dengan kategori berkembang sesuai harapan (BSH) dan 7 anak $(43,7 \%)$ dengan kategori berkembang sangat baik (BSB).
Berdasarkan hasil data analisis observasi Siklus II pada pertemuan ketiga yaitu ketelitian 99,9\%, keluwesan $100 \%$ dan kerapian $81,2 \%$. Nilai rata-rata ketuntasan kemampuan motorik halus Siklus II pada pertemuan ketiga yaitu $93,7 \%$.

\section{Refleksi}

1. Pada siklus II pertemuan pertama peneliti melaksanakan penelitian pada hari Senin. Walaupun waktu penelitian sudah cukup banyak tetapi tempat penelitian di pertemuan ini berada di ruangan aula sekolah dimana ruangan tersebut sangat luas sehingga membuat beberapa anak berlari-lari dan tidak memperhatikan peneliti menjelaskan pembelajaran ditambah lagi terdapat beberapa anak yang masih didampingi oleh orang tuanya.

2. Beberapa anak mulai antusias saat peneliti menjelaskan pembelajaran.

3. Terlihat adanya peningkatan pada aspek ketelitian, keluwesan dan kerapian dimana pada ketiga aspek tersebut sudah tidak ada anak yang mendapatkan nilai BB (Belum Berkembang).

4. Pada siklus II pertemuan kedua peneliti melaksanakan penelitian seperti biasa dan terlihat beberapa anak mulai antusias saat peneliti menjelaskan pembelajaran.

5. Terlihat adanya peningkatan pada aspek ketelitian, keluwesan dan kerapian dimana pada ketiga aspek tersebut sudah tidak ada anak yang mendapatkan nilai 
BB (Belum Berkembang) dan pada aspek keluwesan tidak ada anak yang mendapat nilai MB (Mulai Berkembang).

Berdasarkan hasil keterampilan motorik halus anak pada usia 4-5 tahun melalui kegiatan merobek kertas menunjukkan bahwa adanya peningkatan dari siklus I ke siklus II. Pada siklus II pertemuan pertama, kedua dan ketiga, jumlah nilai rata-rata perolehan skor 3 dan 4 dapat terlihat pada tabel dibawah ini:

Tabel . 3 Rekapitulasi Keterampilan Motorik Halus Anak Melalui Kegiatan Merobek Kertas Siklus II

\begin{tabular}{|c|c|c|c|c|c|}
\hline $\begin{array}{c}\mathrm{N} \\
\mathrm{o}\end{array}$ & $\begin{array}{l}\text { Aspek yang } \\
\text { dinilai }\end{array}$ & $\mathrm{P} 1$ & $\mathrm{P} 2$ & $\mathrm{P} 3$ & $\begin{array}{c}\text { Nilai } \\
\text { rata- } \\
\text { rata }\end{array}$ \\
\hline 1 & Ketelitian & $\begin{array}{l}86,6 \\
\%\end{array}$ & $\begin{array}{l}93,3 \\
\%\end{array}$ & $\begin{array}{l}99,9 \\
\%\end{array}$ & $93,2 \%$ \\
\hline 2 & Keluwesan & $\begin{array}{l}93,2 \\
\%\end{array}$ & $\begin{array}{l}100 \\
\%\end{array}$ & $\begin{array}{l}100 \\
\%\end{array}$ & $97,7 \%$ \\
\hline 3 & Kerapian & $\begin{array}{l}59,9 \\
\%\end{array}$ & $\begin{array}{l}73,2 \\
\%\end{array}$ & $\begin{array}{l}81,2 \\
\%\end{array}$ & $71,4 \%$ \\
\hline \multicolumn{6}{|c|}{ Nilai ketuntasan siklus II } \\
\hline \multicolumn{6}{|c|}{} \\
\hline \multicolumn{6}{|c|}{} \\
\hline
\end{tabular}

Hasil keterampilan motorik halus anak melalui kegiatan merobek kertas pada siklus II mengalami peningkatan dari siklus I, nilai ketuntasan pada siklus II sebesar 87,4\%.

Berdasarkan data keterampilan motorik halus pada anak usia 4-5 tahun melalui kegiatan merobek kertas pada siklus II pada pertemuan pertama, kedua dan ketiga menunjukkan adanya peningkatan yaitu dengan nilai ketuntasan $87,4 \%$ dan telah melebihi indikator keberhasilan yang ditentukan yaitu sebesar $85 \%$. Keterampilan motorik halus anak antar siklus dapat dilihat pada tabel dan grafik berikut ini:
Tabel.4 Hasil Pengamatan Kemampuan Motorik Halus Anak Melalui Kegiatan Merobek Kertas Antar Siklus

\begin{tabular}{|c|c|c|c|c|}
\hline No & $\begin{array}{c}\text { Aspek yang } \\
\text { dinilai }\end{array}$ & $\begin{array}{c}\text { Pra } \\
\text { Siklus } \\
\end{array}$ & $\begin{array}{c}\text { Siklus } \\
\text { I }\end{array}$ & $\begin{array}{c}\text { Siklus } \\
\text { II }\end{array}$ \\
\hline 1 & Ketelitian & $22,1 \%$ & $58,1 \%$ & $93,2 \%$ \\
\hline 2 & Keluwesan & $44,3 \%$ & $74,1 \%$ & $97,7 \%$ \\
\hline 3 & Kerapian & $27,7 \%$ & $50,5 \%$ & $71,4 \%$ \\
\hline \multicolumn{2}{|c|}{$\begin{array}{l}\text { Nilai ketuntasan } \\
\text { antar siklus }\end{array}$} & $31,3 \%$ & $60,9 \%$ & $87,4 \%$ \\
\hline
\end{tabular}

Berdasarkan data di atas keterampilan motorik halus anak usia 4-5 tahun melalui kegiatan merobek kertas menunjukkan adanya peningkatan dan telah mencapai indikator keberhasilan, maka penelitian tindakan kelas untuk meningkatkan motorik halus anak melalui kegiatan merobek kertas dinyatakan berhasil.

\section{Pembahasan}

Penelitian tindakan kelas ini dilaksanakan untuk meningkatkan motorik halus pada anak usia 4-5 tahun di TK Negeri 2 Samarinda yang terdiri dari dua siklus. Setiap siklus terdiri dari tiga kali pertemuan dimana setiap pertemuannya terdapat beberapa tahap yaitu perencanaan, pelaksanaan, observasi dan refleksi.. Merobek merupakan kegiatan kreatif yang menarik bagi anak-anak. Merobek merupakan teknik dasar untuk membuat aneka kerajinan tangan, bentuk hiasan dan gambar dari bahan kertas dengan dirobek secara langsung dengan menggunakan tangan (Sumanto, 2005).

Anak usia 4-5 tahun memiliki karakteristik perkembangan motorik yaitu menjahit sederhana, menempel, menyusun 
puzzle, makin terampil menggunakan jari dan tangan (mewarnai dengan rapi), mengancingkan kancing baju, dan senang dengan gerakan sendiri (Yudha, 2005). Siklus I belum terjadi peningkatan pada pertemuan pertama, kedua dan ketiga hasil dari semua pertemuan tersebut menunjukkan nilai rata-rata $60,9 \%$ dan angka tersebut belum memenuhi indikator keberhasilan yang ingin dicapai, hal tersebut dikarenakan pada pertemuan pertama dan kedua peneliti merasa gugup dan canggung dengan anak, beberapa anak masih didampingi oang tuanya dan dari pihak sekolah hanya memberi izin penelitian seminggu sekali dan tidak memberi izin penelitian di hari lain kecuali hari Jumat. Pada pertemuan selanjutnya peneliti sudah merencanakan kegiatan untuk pertemuan ketiga, tetapi rencana tersebut tidak berjalan dengan lancar dikerenakan adanya kendala tertentu yaitu pada mingguminggu berikutnya sekolah mengadakan acara dan para guru mengikuti pelatihan, sehingga penelitian untuk sementara ditunda sampai 4 minggu lamanya yang mengakibatkan kegiatan pada pertemuan yang sudah direncanakan harus ditunda. Pada pertemuan ketiga, peneliti berkonsultasi dengan pihak sekolah terkait kegiatan dan tema yang sudah peneliti rencanakan sebelumnya, apakah perlu diubah atau tidak, tetapi dari pihak sekolah memberi izin menggunakan tema yang sudah peneliti tentukan pada minggu sebelumnya hanya saja pembahasannya dikaitkan dengan tema yang harusnya minggu itu dilaksaksanakan.

Siklus II terjadi peningkatan pada pertemuan pertama, kedua dan ketiga hasil dari semua pertemuan tersebut menunjukkan nilai rata-rata $87,4 \%$ dan angka tersebut telah memenuhi indikator keberhasilan. Pada pertemuan pertama dan kedua semua berjalan lancar sesuai rencana peneliti, pada pertemuan ini peneliti telah mendapat izin dari sekolah bahwa boleh melakukan penelitian selain hari Jumat karena diminggu tersebut bertepatan dengan masukknya anakanak usia 4-5 tahun ke sentra seni. Dalam pertemuan pertama dan kedua terlihat adanya peningkatan pada aspek ketelitian, keluwesan dan kerapian dimana pada ketiga aspek tersebut sudah tidak ada anak yang mendapatkan nilai Belum Berkembang. Alasan dipilihnya kegiatan merobek kertas karena merupakan kegiatan yang menuntut adanya penggunaaan otot-otot tangan/jari, koordinasi mata dan keterampilan tangan, melatih pengamatan, memupuk ketelitian dan kerapian serta mengembangkan ekspresi melalui media kreatif menurut Montolalu, dkk (Fitri, 2017).

Siklus II pertemuan ketiga terlihat adanya peningkatan pada aspek ketelitian dan keluwesan dimana pada ketiga aspek tersebut sudah tidak ada anak yang mendapatkan nilai Mulai Berkembang. Terdapat dampak positif setelah melakukan kegiatan merobek kertas yaitu anak-anak mulai leluasa serta tidak kaku saat menggerakkan jari jemari mereka 
pada saat merobek, mengkoordinasikan mata dan tangan mereka untuk mengikuti pola pada yang dirobek, anak-anak sudah tidak jijik dan merasa tidak nyaman pada saat mereka menggunakan lem. Bahkan pada pertemuan ketiga ini ada beberapa anak yang minta kertas gambar pola yang disobek untuk mereka sobek kembali. Kegiatan pembelajaran motorik halus anak merasa tidak jenuh dan bosan sehingga mereka tidak sadar kalau dirinya sedang belajar. Kegiatan merobek, menempel dan menggunting kertas dapat melatih motorik halus anak diantaranya melatih koordinasi antara mata dan otot-otot kecil jemari anak, melatih otot lengan anak dan jari jemarinya, seperti menggenggam benda dengan jari tangan (Syarif, 2010). Pada siklus II ini karena hasil penelitian pada kegiatan merobek kertas yang mendapat skor 3 berkembang sesuai harapan (BSH) dan skor 4 berkembang sangat baik (BSB) sudah mencapai indikator keberhasilan yaitu $87,4 \%$ maka penelitian dinyatakan berhasil.

\section{PENUTUP}

\section{Kesimpulan}

Berdasarkan hasil analisis data dari pembahasan dan hasil penelitian dapat disimpulkan bahwa adanya peningkatan terhadap keterampilan motorik halus melalui kegiatan merobek kertas pada anak usia 4-5 tahun di TK Negeri 2 Samarinda. Berdasarkan siklus I setelah melaksanakan pertemuan pertama, kedua dan ketiga menunjukkan bahwa keterampilan motorik halus melalui kegiatan merobek kertas pada anak usia 4-5 tahun mencapai 60,9\%, kemudian meningkat $26,5 \%$ dan mencapai keberhasilan pada siklus II setelah melaksanakan pertemuan pertama, kedua dan ketiga mencapai $87,4 \%$.

\section{DAFTAR PUSTAKA}

Aep Rohendri \& Laurens Seba. (2017). Perkembangan Motorik Pengantar Teori dan Implikasinya dalam Belajar. Bandung: Alfabeta.

Arikunto, Suharsimi., Dkk. (2008). Penelitian Tindakan Kelas. Jakarta: Bumi Aksara.

Fahmi Gunawan, dkk. (2018). Senarai Penelitian Pendidikan, Hukum dan Ekonomi di Sulawesi Tenggara. Yogyakarta: CV Budi Utama.

Haryadi Malvyandie. (2016). Alasan Batita Senang Merobek dan Manfaat Bagi Mereka. Diperoleh 23 Januari 2019 dari https://www.tribunnews.com/kesehatan/20 16/08/04/ternyata-ini-alasan-batita-senangmerobek-dan-manfaatnya-bagi-mereka

Latif, Mukhtar. (2016). Orientasi Baru Pendidikan Anak Usia Dini: Teori dan Aplikasi. Jakarta: Prenadamedia Group.

Muliawan, Ungguh Jasa. (2018). Penelitian Tindakan Kelas (Classroom Action Research). Yogyakarta: Penerbit Gava Media.

Mulyani, Novi. (2018). Pengembangan Dasar Anak Usia Dini. Yogyakarta: Penerbit Gava Media.

Mulyati, Atik. (2014). Peningkatan Keterampilan Motorik Halus Melalui Origami Pada Anak Kelompok A Tk Kusuma Baciro Gondokusuman Yogyakarta. Diperoleh 20 Januari 2019 dari http://eprints.uny.ac.id/13016/1/Skripsi_At ik.MulyatiNIM.12111247007.pdf. Yogyakarta. Universitas Negeri Yogyakarta

Paizaluddin \& Ermalinda. (2016). Penelitian Tindakan Kelas (Classroom Action Research). Bandung: Alfabeta.

Permendikbud No 137. (2014). Standar Nasional Pendidikan Anak Usia Dini: Jakarta

Pratiwi Dian Afrina. (2016). 
Mengembangkankemampuan Motorik Halus Anak Melalui Kegiatan Merobek Kertas Berpola Pada Anak Usia 3-4 Tahun Di Paud Aisyiyah Ii Ngadiluwih Kabupaten Kediri Tahun Pelajaran 2015/2016. Diperoleh 12 maret 2019 dari http://simki.unpkediri.ac.id/mahasiswa/file artikel/2017/12.1.01.11.0475.pdf. Kediri. Universitas Nusantara PGRI Kediri.

Sugiyono. (2015). Metode Penelitian Tindakan Komprehensif. Bandung: Alfabeta.

Sujiono, Bambang. Dkk. (2014). Materi Pokok Metode Pengembangan Fisik. Tanggerang Selatan: Universitas Terbuka.

Sumanto. (2005). Pengembangan Kreativitas Seni Rupa Anak TK. Jakarta: Departemen Pendidikan Nasional.

Suryadi \& Dahlia. (2014). Implementasi dan Inovasi: Kurikulum Paud 2013. Bandung: PT Remaja.

Susanto, Ahmad. (2017). Pendidikan Anak Usia Dini (Konsep dan Teori). Jakarta: Bumi Aksara.

Syarif Sumantri \& Mursanah. (2010). Pengaruh Kegiatan Bermain Kertas Terhadap Peningkatan Ketermpilan Motorik Halus Anak Usia 4-5 Tahun di TK AL-Qomal Mandalawangi Kabupaten Pandeglang. Diperoleh 03 Oktober 2019 dari art001506610920161028074721.pdf.

Yani, Fitri. (2017). Meningkatkan Perkembangan Motorik Halus Anak Melalui Kegiatan Merobek Kertas Di Ra Iqra' Sabila Kota Jambi. Diperoleh 20 Januari 2019 dari http://repository.fkip.unja.ac.id/. Jambil. Universitas Jambi.

Yudha M. Saputra \& Rudyanto. (2005). Pembelajaran Kooperatif untuk Meningkatkan Keterampilan Anak TK. Jakarta: Departemen Pendidikan Nasional, Direktorat Jenderal Pendidikan Tinggi, Direktorat Pendidikan Tenaga Kependidikan dan Ketenagaan Perguruan Tinggi. 